\title{
Response of Chickpea (Cicer arietinum L.) Productivity under Different Irrigation Frequencies and Mulching
}

\author{
D. Komal $^{1 *}$, S.R. Bhakar ${ }^{1}$, S.S. Lakhawat ${ }^{2}$, B.G. Chhipa ${ }^{2}$ and Manjeet Singh ${ }^{1}$ \\ ${ }^{1}$ Department of Soil and Water Engineering, C.T.A.E, MPUAT, Udaipur-313001, \\ Rajasthan, India \\ ${ }^{2}$ Department of horticulture, RCA, MPUAT, Udaipur-313001, Rajasthan, India \\ *Corresponding author
}

\section{A B S T R A C T}

\section{Keywords}

Chickpea, Mulch, Irrigation schedule, Yield

Article Info

Accepted:

24 August 2018

Available Online:

10 September 2018
A field experiment entitled "Response of chickpea (Cicer arietinum L.) productivity under different irrigation frequencies and mulching" was conducted during rabi season from $13^{\text {th }}$ October, 2017 to $19^{\text {th }}$ February, 2018 At plasticulture farm of CTAE, Udaipur. (Rajasthan). The experiment consist of nine treatment combination; Irrigation based on field capability at three irrigation frequencies of $\mathrm{I}_{1}$-single irrigation (at pre sowing only), $\mathrm{I}_{2}$-double irrigation (at pre sowing + flowering stage) and $\mathrm{I}_{3}$-triple irrigation (at pre sowing + flowering stage + pod filling stage) irrigation frequencies along with; $\mathrm{M}_{0}$-Black plastic mulch (BPM), $\mathbf{M}_{1}$-Polypropylene woven mulch (PPWM) and $\mathbf{M}_{2}$-No mulch (NM) were laid out with three replications in factorial randomized block design (FRBD). Mulching and irrigation frequencies significantly influenced the growth and yield attributes at harvest maximum plant height $(77.67 \mathrm{~cm})$, number of primary branches per plant $(28.50)$, number of pod/plant (37.33), seed weight/pod $(0.21 \mathrm{gm})$, and yield/hectare $(20.29 \mathrm{q})$ higher in treatment combination of $\mathrm{M}_{1}$-PPWM and $\mathrm{I}_{2}$-double irrigation i.e. treatment $\left(\mathrm{T}_{5}\right)$.

\section{Introduction}

Chickpea (Cicer arietinum L.) is most important rabi pulse crop of India. Pulses are an important commodity group of crops that provide high quality protein. Pulses are mostly cultivated rainfed condition that's why shortage of soil moisture in the rainfed agriculture areas occurs during the most sensitive growth stage (flowering and pod filling stages) of rabi crops.

The modern technology of drip irrigation is successfully practiced in many countries for orchards, vegetables, ornamental crops and as well as high value field crops. It is gaining momentum and its prospects in the years to come are expected to be very bright. Though India has the largest irrigation network, the irrigation efficiency does not exceed $40 \%$. Due to water scarcity, the available water resources should be very effectively utilized through water saving irrigation technologies. Hence, further expansion of irrigation may depend upon the adoption of new systems such as pressurized irrigation methods with the limited water resources (Kumar et al., 2016). 
Mulching reduces the deterioration of soil, minimizes the weed infestation and checks the water evaporation. Thus, it facilitates more retention of soil moisture and helps in control of temperature fluctuations, improves physical, chemical and biological properties of soil. As it adds nutrients to the soil and ultimately enhances the growth and yield of crops. Inorganic mulch includes plastic mulch and accounts for the greatest volume of mulch use in commercial crop production. The plastic materials used as mulch are polyvinyl chloride or polyethylene films.

\section{Materials and Methods}

\section{Study area}

Field experiment was conducted for chickpea crop during rabi season from $13^{\text {th }}$ October, 2017 to $19^{\text {th }}$ February, 2018, at plasticulture farm, College of Technology and Engineering, MPUAT Udaipur (Rajasthan). Geographically, Udaipur is located at $24^{\circ} 35 \mathrm{~N}$ latitude and $73^{\circ} 44 \mathrm{E}$ longitudes.

The altitude of the site is $582.17 \mathrm{~m}$ above mean sea level. The area has a sub-humid climate. The average annual rainfall in the region is $662.5 \mathrm{~mm}$ and more than $80 \%$ of this amount is received as a part of south-west monsoon during the period of $16^{\text {th }}$ June to $15^{\text {th }}$ September.

\section{Experimental details}

Experiment was laid out in factorial Randomized block design (FRBD) with three replications. Plot size was $15 \times 1 \mathrm{~m}^{2}$ and plant spacing was $30 \times 10 \mathrm{~cm}^{2}$. Nine treatment combination; Irrigation based on field capability at three irrigation frequencies of $\mathrm{I}_{1}$ single irrigation (at presowing only), $\mathrm{I}_{2}$-double irrigation (at pre sowing + flowering stage) and $\mathrm{I}_{3}$-triple irrigation (at presowing + flowering stage + pod filling stage) irrigation frequencies along with; $\mathbf{M}_{0}$-Black plastic mulch (BPM), $\mathrm{M}_{1-}$ Polypropylene woven mulch (PPWM) and $\mathrm{M}_{2}$-No mulch (NM).

Plant height, number of primary branches per plant, number of pods per plant, seed weight per pod (gm), yield per hectare (q), 5\% level of significance was considered in ANOVA to test the influence of mulching and irrigation frequencies on growth and yield attributes of chickpea.

\section{Results and Discussion}

The effect of mulching, irrigation frequencies and their interaction on growth and yield attributes are presented in Table 1 and interaction effect of mulching and irrigation frequencies on growth and yield attributes depicted in Figure 1 to 5.

Net water requirement of chickpea was found to be single irrigation $70 \mathrm{~mm}$ presowing only, double irrigation $144 \mathrm{~mm}$ at presowing and flowering stage and triple irrigation $216 \mathrm{~mm}$ at presowing, flowering stage and pod filling stage. At harvest maximum plant height $(77.67 \mathrm{~cm})$, number of primary branches per plant (28.50), number of pods per plant (37.33), seed weight per pod (0.21 gm) and yield per hectare (20.29 q).

The result showed the maximum growth and yield attributes was recorded in treatment combination of $\mathrm{M}_{1}$ (PPWM) and irrigation frequencies $\mathrm{I}_{2}$ (at pre sowing + flowering stage) i.e. treatment $\left(T_{5}\right)$ then the minimum growth and yield attributes was recorded in treatment combination of $\mathrm{M}_{0}(\mathrm{NM})$ and irrigation frequencies $\mathrm{I}_{1}$ (at pre sowing) i.e. treatment $\left(\mathrm{T}_{1}\right)$. Similar results were reported mulching treatments crop mulched with PPWM and BPM showed superiority over no mulch. Awal et al., (2016) reports that mulching treatment increase plant height and number primary branches per plant. 
Table.1 Effect of mulching, irrigation frequencies and their interaction on growth and yield attributes of chickpea

\begin{tabular}{|c|c|c|c|c|c|}
\hline \multirow[t]{2}{*}{ Treatments } & \multicolumn{5}{|c|}{ Yield parameters } \\
\hline & $\begin{array}{c}\text { Plant } \\
\text { height }(\mathbf{c m})\end{array}$ & $\begin{array}{c}\text { Number of primary } \\
\text { branches/plant }\end{array}$ & $\begin{array}{l}\text { Number of } \\
\text { pods/plant }\end{array}$ & $\begin{array}{c}\text { Seed weight/pod } \\
\text { (gm) }\end{array}$ & $\begin{array}{c}\text { Yield/ } \\
\text { hectare (q) }\end{array}$ \\
\hline \multicolumn{6}{|l|}{ Mulch (M) } \\
\hline $\mathrm{M}_{0}(\mathrm{NM})$ & 60.89 & 22.67 & 26.78 & 0.142 & 12.9 \\
\hline $\mathbf{M}_{1}(\mathbf{P P W M})$ & 73.22 & 26.92 & 35 & 0.192 & 18.98 \\
\hline $\mathrm{M}_{2}(\mathrm{BPM})$ & 70.01 & 25.51 & 32.78 & 0.179 & 17.77 \\
\hline S.Em \pm & 1.4 & 0.52 & 0.57 & 0.003 & 0.28 \\
\hline C.D.5\% & 4.21 & 1.57 & 1.71 & 0.009 & 0.85 \\
\hline \multicolumn{6}{|l|}{ Irrigation (I) } \\
\hline$I_{1}$ & 64.56 & 23.82 & 29.78 & 0.155 & 14.79 \\
\hline$I_{2}$ & 70.23 & 26.12 & 32.56 & 0.18 & 17.58 \\
\hline$I_{3}$ & 69.33 & 25.16 & 32.22 & 0.178 & 17.28 \\
\hline S.Em \pm & 1.4 & 0.52 & 0.57 & 0.003 & 0.28 \\
\hline C.D.5\% & 4.21 & 1.57 & 1.71 & 0.009 & 0.85 \\
\hline \multicolumn{6}{|c|}{ Interaction $(\mathbf{M} \times \mathbf{I})$} \\
\hline$M_{0} I_{1}\left(T_{1}\right)$ & 58.00 & 22.00 & 25.67 & 0.13 & 10.22 \\
\hline$M_{0} I_{2}\left(T_{2}\right)$ & 60.00 & 22.90 & 26.33 & 0.14 & 13.89 \\
\hline $\mathbf{M}_{0} \mathbf{I}_{3}\left(\mathbf{T}_{3}\right)$ & 64.67 & 23.10 & 28.33 & 0.15 & 14.58 \\
\hline$M_{1} I_{1}\left(T_{4}\right)$ & 68.00 & 25.10 & 32.33 & 0.17 & 17.87 \\
\hline $\mathbf{M}_{1} \mathbf{I}_{2}\left(\mathrm{~T}_{5}\right)$ & 77.67 & 28.50 & 37.33 & 0.21 & 20.29 \\
\hline$M_{1} I_{3}\left(T_{6}\right)$ & 74.00 & 27.17 & 35.33 & 0.20 & 18.78 \\
\hline $\mathbf{M}_{2} \mathbf{I}_{1}\left(\mathbf{T}_{7}\right)$ & 67.67 & 24.37 & 31.33 & 0.16 & 16.27 \\
\hline $\mathbf{M}_{2} \mathbf{I}_{2}\left(\mathbf{T}_{8}\right)$ & 73.03 & 26.97 & 34.00 & 0.19 & 18.55 \\
\hline $\mathbf{M}_{2} \mathbf{I}_{3}\left(\mathbf{T}_{9}\right)$ & 69.33 & 25.20 & 33.00 & 0.18 & 18.49 \\
\hline S.Em \pm & 2.43 & 0.91 & 0.99 & 0.01 & 0.49 \\
\hline C.D.5\% & 7.29 & 2.73 & 2.96 & 0.02 & 1.48 \\
\hline
\end{tabular}

Fig.1 Interaction effect of mulching and irrigation frequencies on plant height

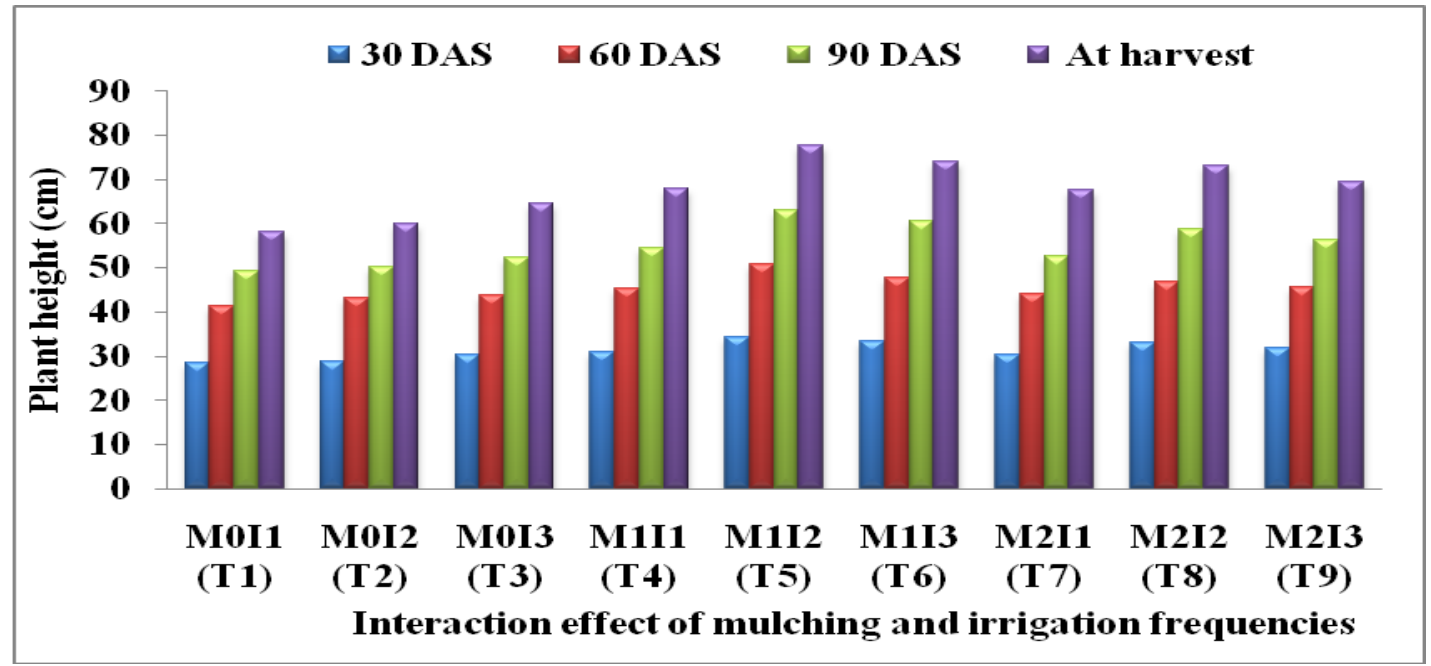


Fig.2 Interaction effect of mulching and irrigation frequencies number of Primary branches per plant

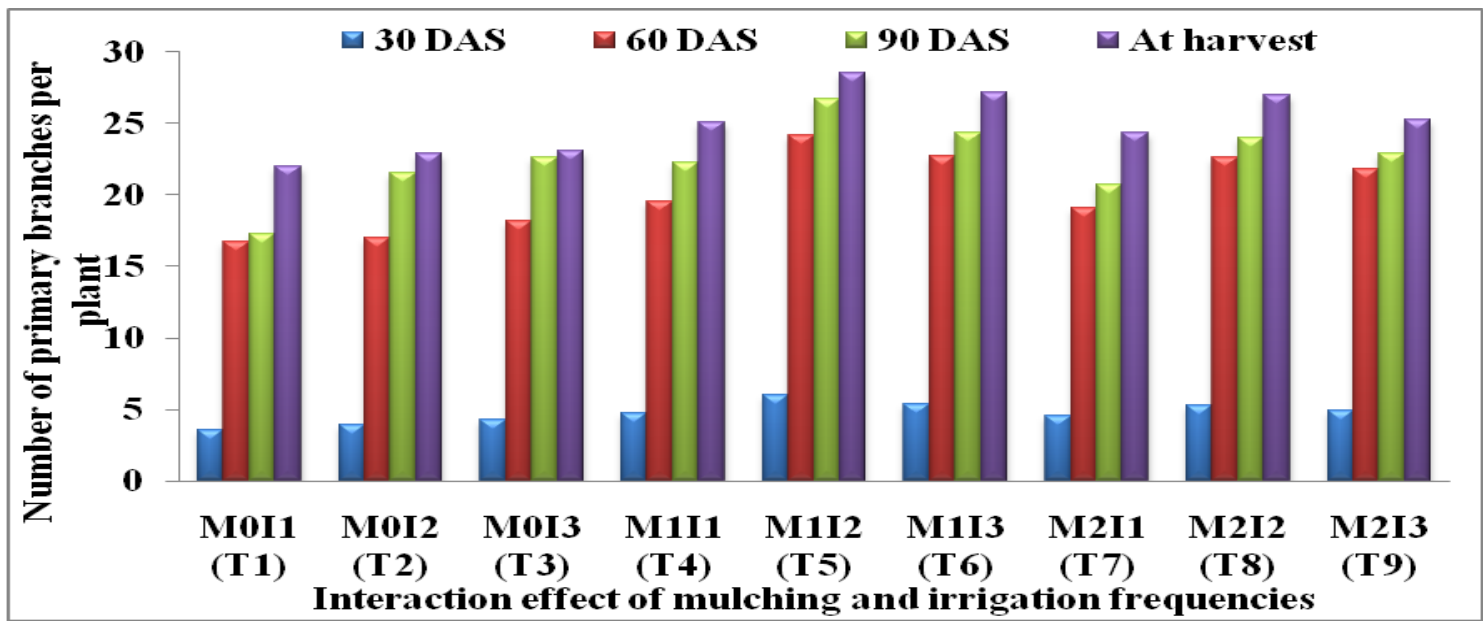

Fig.3 Interaction effect of mulching and irrigation frequencies on number of pods per plant

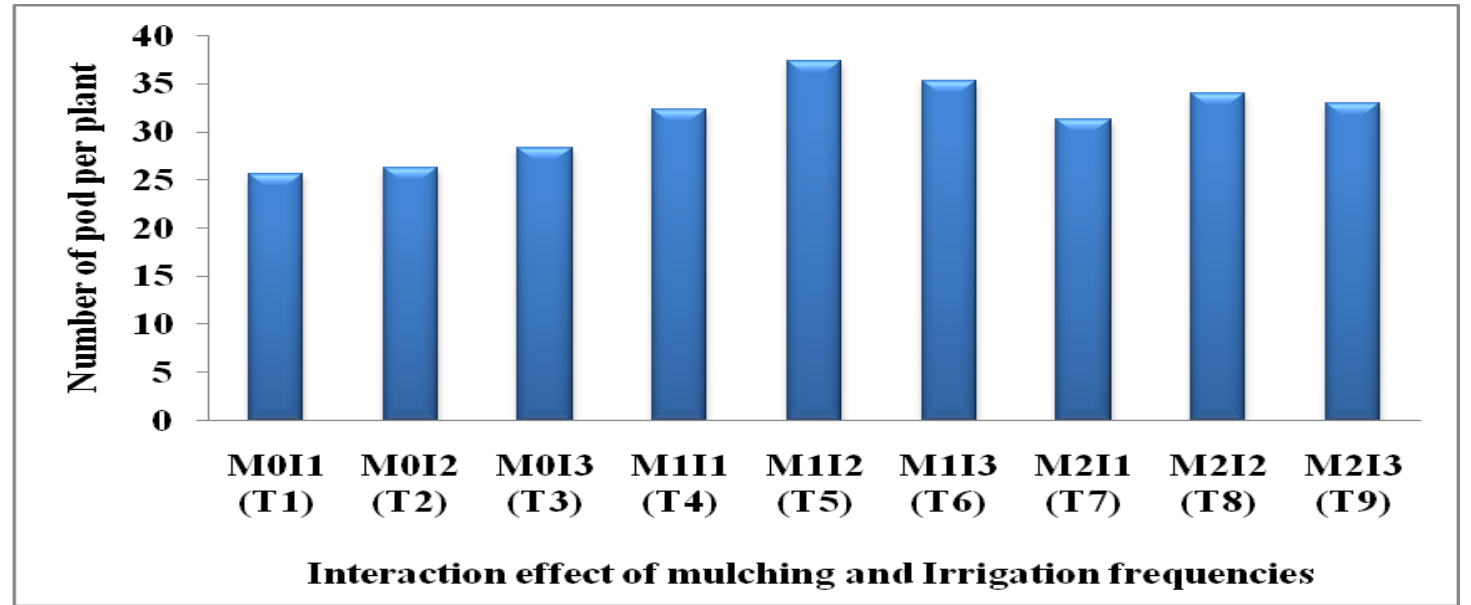

Fig.4 Interaction effect of mulching and irrigation frequencies on seed weight per pod (gm)

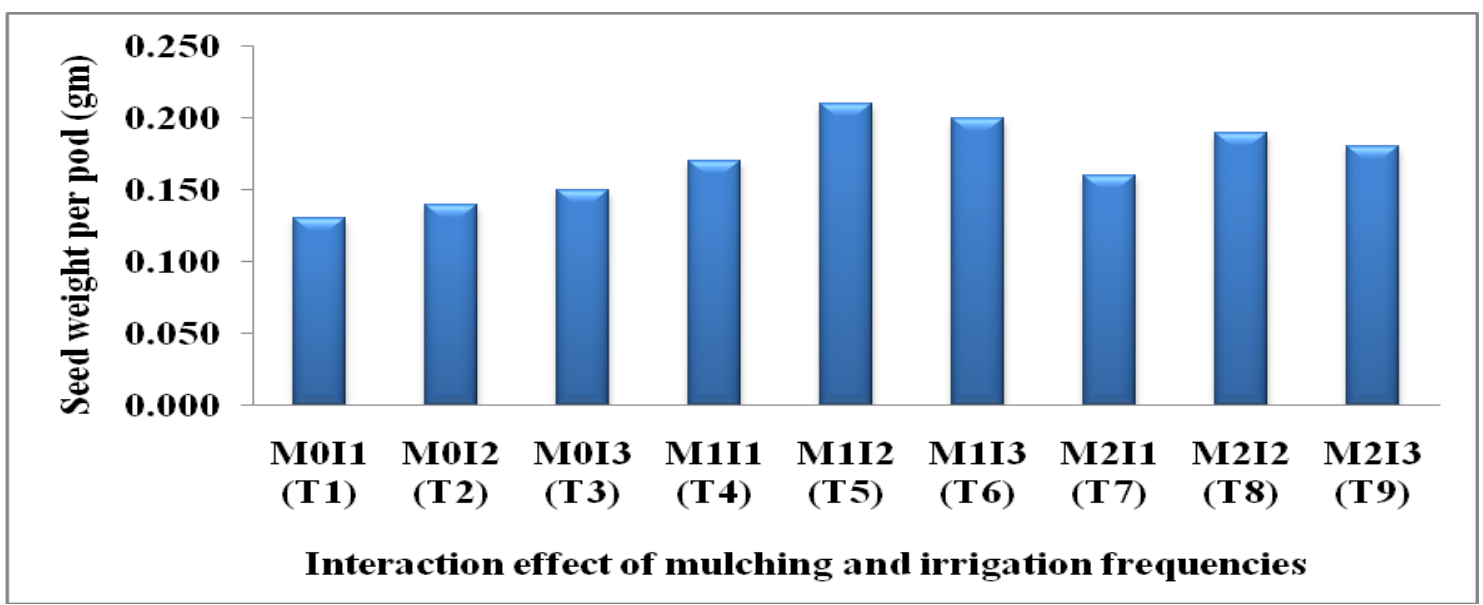


Fig.5 Interaction effect of mulching and irrigation frequencies on yield per hectare

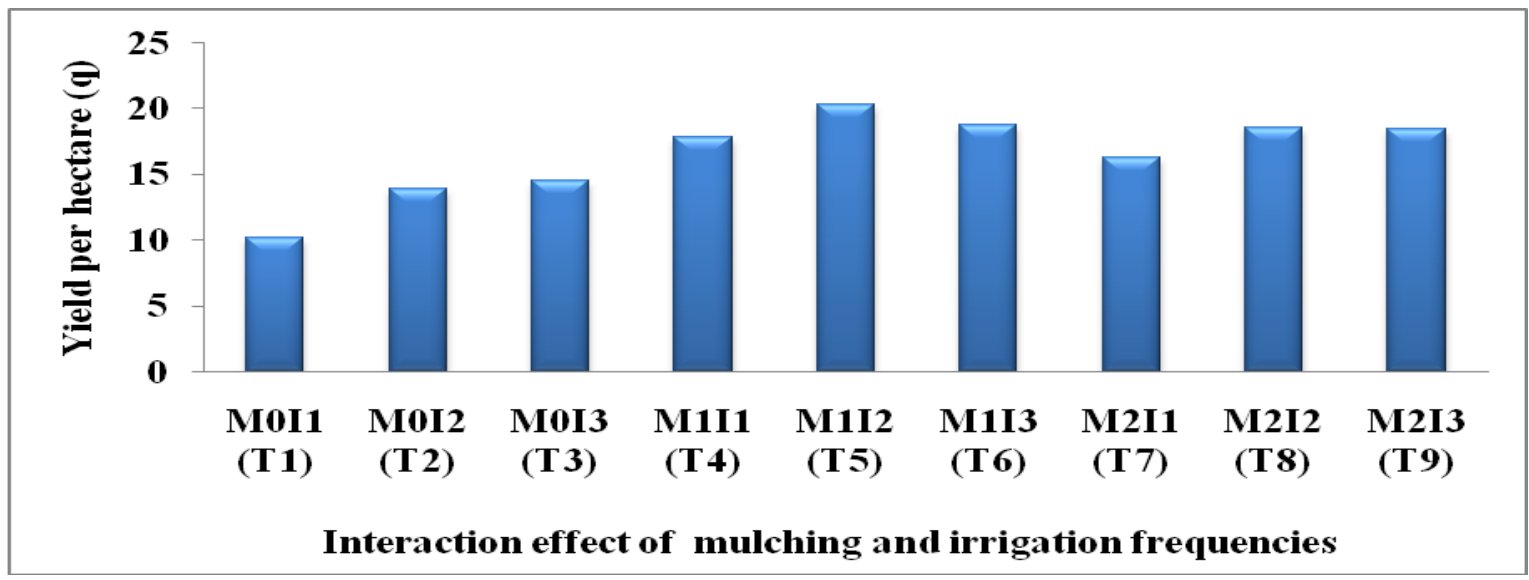

Treatment combination of double irrigation and triple irrigation treatment recorded significantly higher plant height and number primary branches per plant than single irrigation. Krishnamurthy and Steeramula (2007) also observed similar results that highest grain yield $(1968.65 \mathrm{~kg} / \mathrm{ha})$ was irrigated at flowering stage and pod formation stage. Birbal et al., (2013) observed results interaction effect between drip irrigation and mulch increased growth and yield attributes.

From this study, growth and yield attributes such as plant height (77.67), number of primary branches per plant (28.50), number of pods per plant (37.33), seed weight per pod $(0.21 \mathrm{gm})$ and yield per hectare (20.29 q). Higher in treatment combination $\mathrm{M}_{1}$ (PPWM) and irrigation frequencies $\mathrm{I}_{2}$ (at pre sowing + flowering stage) i.e. treatment $\left(\mathrm{T}_{5}\right)$ and BPM compare to treatment combination $\mathrm{M}_{0}(\mathrm{NM})+$ $\mathrm{I}_{1}$ (pre sowing) i.e. treatment $\left(\mathrm{T}_{1}\right)$.

\section{References}

Awal, M.A., Dhar, P.C. and Satu, S.M. 2016. Effect of mulching on microclimatic manipulation, weed suppression and growth and yield of pea (Pisum sativum L.) Journal of Agriculture and Ecology Research International 8: 1-12.

Birbal, Rathore, V.S., Nathawat, N.S., Bhardwaj S. and. Yadava N.D. 2013. Influence of irrigation methods and mulches on pea (Pisum sativum L.) in ber (Ziziphus mauritiana) based vegetable production system under tropical climate of Rajasthan. Legume Resource 36: 557562.

Krishnamurthy, S.K. and Steeramulu, E. 2007. Yield and yield attributes of Bengal gram as influenced by time of sowing and number of irrigation during rabi season. Crop Research-HISAR 33: 65-67.

Kumar R., Pal, R., Kumar, R., Sagar. S. and A.S. Bist. 2016. Response of water use Efficiency through fertigation on growth and yield of chilli crop. International Journal of Engineering Sciences and Research Technology 5: 1-9.

\section{How to cite this article:}

Komal, D., S.R. Bhakar, S.S. Lakhawat, B.G. Chhipa and Manjeet Singh. 2018. Response of Chickpea (Cicer arietinum L.) Productivity under Different Irrigation Frequencies and Mulching. Int.J.Curr.Microbiol.App.Sci. 7(09): 3638-3642.

doi: https://doi.org/10.20546/ijcmas.2018.709.452 